\title{
Sources of exposure to and public health implications of organophosphate pesticides
}

\author{
Kushik Jaga ${ }^{1}$ and Chandrabhan Dharmani ${ }^{2}$
}

ABSTRACT Objective. To review the public health significance of organophosphate pesticide exposure in the United States of America. Since the situation of high organophosphate pesticide exposure and the concomitant health risks in the developing countries of the world is well known, this article seeks to highlight the public health significance of organophosphate exposure in the United States, where it is less common than in many other nations. Looking at the situation in the United States would serve to further emphasize the seriousness of organophosphate pesticide-related health issues in developing countries.

Methods. A search for journal articles on organophosphate pesticides and organophosphate exposure was done on the PubMed electronic bibliographic database system of the National Library of Medicine of the United States. To supplement that search, information on organophosphate toxicity, biological monitoring, and regulation of pesticides was obtained from other published articles, textbooks, and relevant Internet sites.

Results. Organophosphate pesticides are a group of chemicals that are mainly used in agriculture. Organophosphates inhibit the activity of both the cholinesterase (ChE) enzymes-red blood cell (RBC) ChE and serum ChE-resulting in the cholinergic features of organophosphate toxicity. A 50\% reduction in serum ChE activity from the baseline is an indication of acute organophosphate toxicity. The RBC ChE activity, which is less rapidly depressed than the serum ChE activity, is a measure of chronic exposure to organophosphates. Exposures to organophosphates are broadly classified into two categories: occupational and environmental. Occupational exposures occur among agricultural workers (including migrant farmworkers), industrial workers, pest control exterminators, and other workers. Nonoccupational exposure affects a large segment of the general population in the United States. Residential exposures come from organophosphate pesticide use by exterminators and by household residents as well as from dietary and accidental exposures. Other environmental exposures occur in public places and areas close to farms, and exposures could also happen from organophosphate use in chemical warfare or terrorism. In the United States some organophosphate pesticides are restricted by the Environmental Protection Agency in order to protect humans, animals, and the environment. In addition, the Food Quality Protection Act regulates dietary exposure to pesticides, particularly for infants and children.

Conclusions. Organophosphate pesticides continue to pose a risk to human health in the United States. Biological monitoring should be used to strictly regulate occupational exposures to organophosphates and thus protect the health and safety of workers. Among the public there should be an increased awareness of environmental exposure to organophosphates as well as of the threat of chemical warfare or terrorism.

Key words Pesticides; insecticides, organophosphate; occupational exposure; environmental exposure; environmental monitoring; government regulation; United States of America.

1 VA Hudson Valley Healthcare System, Montrose Research Corporation, Montrose, New York, United States of America. Send correspondence to: Kushik Jaga, P.O. Box 358, Elmsford, New York
10523, United States of America or to 51 Eiler Lane, Irvington, New York 10533, United States of America; e-mail: KUSHIK_JAGA@NYMC.edu
2 New York Medical College, School of Public Health, Valhalla, New York, United States of America. 


\section{ORGANOPHOSPHATES}

The organophosphate compounds are a group of insecticides that were first discovered in 1938 by a group of German chemists. Organophosphates were introduced as nerve poisons or chemical warfare agents during World War II, and later they were developed into less potent chemicals $(1,2)$. The organophosphate compounds are used to destroy insects such as fleas, lice, flies, and mosquitoes (3). These chemicals are used for pest control on crops in agriculture and on livestock, for other commercial purposes, and for domestic use, that is, by individuals in their own homes $(2,3)$. Organophosphates have gained popularity worldwide in preference to organochlorines, which are persistent and more damaging to the environment. The organophosphates break down more rapidly than do organochlorines in the environment, they have a milder impact, and they are safer and less persistent $(2,3)$. A list of commonly used organophosphate insecticides registered by the Environmental Protection Agency (EPA) of the United States of America is given in Table 1. As also indicated in Table 1, the use of many organophosphate insecticides has been restricted by the EPA in order to prevent health risks (4).

Pesticide exposure is a global public health issue. The World Health Organization (WHO) has estimated that each year there are some 3000000 cases of acute pesticide poisonings, with 220000 deaths. The majority of these incidents occur in developing countries (5), particularly in Africa, Asia, and Central and South America. In Central America, for example, between 1992 and 2000 the importation of pesticides increased noticeably, the incidence rate of acute pesticide poisoning rose from 6.3 per 100000 population to 19.5 per 100000 population, and the mortality rate climbed from 0.3 per 100000 population to 2.1 per 100000 (6).

Since the situation of high exposure and health risks in developing nations is known, the objective of this article is to highlight the public health significance of organophosphate exposure in

TABLE 1. A list of commonly used organophosphate insecticides registered by the Environmental Protection Agency of the United States of America, including ones whose use is restricted

\begin{tabular}{|c|c|}
\hline Organophosphate insecticides & Organophosphate insecticides (con.) \\
\hline Acephate & Isofenphos ${ }^{\mathrm{a}}$ \\
\hline Azinphos-methyla & Malathion \\
\hline Bensulide & Methamidophos ${ }^{\mathrm{a}}$ \\
\hline Chlorethoxyphos $^{\mathrm{a}}$ & Methidathion ${ }^{a}$ \\
\hline Chlorpyrifos $^{\mathrm{a}}$ & Mevinphos \\
\hline Coumaphos $^{a}$ & Naled \\
\hline Diazinon ${ }^{\mathrm{a}}$ & Phosmet \\
\hline Dichlorvos & Profenofos ${ }^{a}$ \\
\hline Dicrotophos & Propetamphos \\
\hline Dimethoate & Sulfotepp ${ }^{a}$ \\
\hline Disulfoton ${ }^{\mathrm{a}}$ & Sulprofos ${ }^{a}$ \\
\hline Ethion ${ }^{\mathrm{a}}$ & Tebupirimiphos \\
\hline Ethoprop ${ }^{a}$ & Temephos \\
\hline Ethyl parathion ${ }^{a}$ & Terbufos $^{a}$ \\
\hline Fenamiphos $^{\mathrm{a}}$ & Tetrachlorvinphos \\
\hline Fenitrothion ${ }^{\mathrm{a}}$ & Tribufos \\
\hline Fonofos ${ }^{a}$ & Trichlorfon \\
\hline
\end{tabular}

Source: Sullivan JB Jr., Blose J (2).

a Use of this organophosphate is restricted by the Environmental Protection Agency of the United States (4).

an area with less exposure. This in turn would serve to further emphasize the seriousness of pesticide-related health issues in developing countries. We selected the United States for this review. In that country, pesticide exposure affects both persons born there and immigrants. For instance, organophosphate exposure greatly impacts the health of Latin Americans employed as migrant farmworkers in the United States (7).

The organophosphates are commonly used in the United States. Therefore, for the purpose of this review, a literature search on organophosphate pesticides was done on the PubMed electronic bibliographic database system of the National Library of Medicine of the United States. Publications that described the sources of organophosphate exposure were selected. The relevant information from the literature was grouped into occupational exposures and into nonoccupational or environmental exposures. In addition, information on organophosphate toxicity, biological monitoring, and regulation of pesticides was retrieved from other published articles, textbooks, and appropriate Internet sites.

\section{Organophosphate toxicity}

Organophosphate exposure occurs among people who come into contact with the chemicals as a result of their occupation $(3,5)$, and the general population is exposed by the entry and spread of the chemicals into the environment $(1,3)$. Exposure to organophosphates occurs via inhalation, absorption into the skin, and ingestion $(1,2)$. The organophosphate insecticides bind with the cholinesterase $(\mathrm{ChE})$ enzyme at the neuromuscular junction and deactivate or inhibit the activity of the enzyme by irreversible phosphorylation. This results in elevated levels of acetylcholine (ACh), which acts on the muscarinic receptors situated at cholinergic junctions in skeletal nerve-muscular junctions, at nicotinic receptors in autonomic ganglia, and receptors in the central nervous system (CNS) $(2,8)$. Both the red blood cell (RBC) ChE activity and the pseudo (or serum) ChE activity are inhibited by organophosphates. The serum ChE enzyme is inhibited more rapidly and is restored to the normal levels within 60 days, being an indicator of acute organophosphate poisoning. $\mathrm{RBC} C \mathrm{ChE}$ activity is depressed less rapidly by organophosphates and takes 
several weeks to several months to return to its normal level. The RBC ChE enzyme is the preferred measurement for assessing chronic organophosphate exposure, especially in workers exposed to organophosphates $(2,3)$.

High dose levels of organophosphate insecticides cause acute intoxication as a result of increased activity of ACh at muscarinic, nicotinic, and CNS receptors. This manifests as acute cholinergic signs and symptoms of organophosphate poisoning, including gastrointestinal upset, bronchospasm, miosis, urination, sweating, lacrimation, bradycardia, fasciculations, muscle weakness, hypertension, and CNS depression or coma $(2,3)$. In the United States in 1999 more than 13000 cases of organophosphate poisoning were reported to poison centers, there were more than 3000 cases seen in emergency departments, and 83 fatalities occurred (9).

Organophosphate poisoning is treated with atropine and pralidoxime $(2,5)$. Both substances are very effective in reducing the cholinergic effects of organophosphates. Atropine blocks the ACh receptors, thereby preventing the action of $\mathrm{ACh}$ at respective sites. Pralidoxime, in contrast, reverses the ChE inhibition by reactivation of the ChE enzyme.

Following an acute cholinergic crisis, an intermediate syndrome occurs 24 to 96 hours later, which results from presynaptic and postsynaptic neuromuscular dysfunction. This results in acute respiratory muscle paresis, paresis of the proximal limb and facial muscles, and cranial nerve palsies $(1,5)$. An organophosphate-induced delayed neuropathy occurs 2 to 3 weeks after an acute episode of poisoning. Common features of this syndrome are CNS and peripheral nervous system effects of a mixed sensory-motor neuropathy. These cause progressive distal muscle weakness, ataxia in lower limbs, flaccid paralysis, and spasticity $(3,5)$. The syndrome has been correlated with the inhibition of a neurotoxic esterase in the CNS, and not the ChE enzyme. The extent of delayed polyneuropathy is determined by the differences in structural activity of different organophosphate insecticides (1).
People with chronic exposure to organophosphate insecticides at low to moderately high doses develop a pesticide-related illness. These mild to moderate symptoms of organophosphate toxicity include nausea, headache, dizziness, blurred vision, abdominal pain, vomiting, and chest tightness, with $\mathrm{ChE}$ depression (2). Other risks of organophosphate exposure include reproductive effects, spontaneous abortions, and fetal death (10). Both nonHodgkin's lymphoma among farmers and cancers in children have been reported as a result of organophosphate exposure (11). The neurotoxicity of organophosphates manifests as neurobehavioral and neurophysiological effects in people who have experienced acute organophosphate poisoning (12). Rosenstock et al. (13) found that agricultural workers in Nicaragua who had acute organophosphate intoxication suffered from chronic neuropsychological effects. It is not clear whether chronic low-dose exposure to organophosphates causes any neurological impairment in exposed people (12).

\section{SOURCES OF ORGANOPHOSPHATE EXPOSURE}

Organophosphate exposure is a major public health issue in terms of health, morbidity, health care, and general safety from toxicity (14). According to data from the Toxic Exposure Surveillance System of the American Association of Poison Control Centers, there were 10073 exposures to organophosphate insecticides in adults in the United States in the year 2000 (15). Of those exposures, 9609 of them were unintentional and 276 were intentional; 2720 cases were treated at health care facilities.

A simple classification of exposure to organophosphates is: (a) occupational exposure and (b) environmental or nonoccupational exposure $(2,16)$. Unintentional, accidental, or suicidal poisoning can occur in both occupational and nonoccupational exposures to organophosphates $(17,18)$. Homicidal poisoning would include suicide poisoning as well as intentional poisoning of one individual by another (17). Chemical warfare with organophosphates is a form of terrorism, with homicidal poisoning targeted to affect a large population (18). Various situations of organophosphate exposure are outlined in Table 2.

\section{Occupational exposure}

Workers are exposed to pesticides in their workplaces as a result of their occupation. Irrespective of whether the job involves pesticide use, the presence of the chemical in the work en-

TABLE 2. Situations of occupational exposure and of nonoccupational exposure to organophosphates

\begin{tabular}{ll}
\hline \multicolumn{1}{c}{ Occupational exposure } & \multicolumn{1}{c}{$\begin{array}{c}\text { Environmental or } \\
\text { nonoccupational exposure }\end{array}$} \\
\hline Agricultural workers & $\begin{array}{c}\text { Residential exposure: } \\
\text { Manufacturing industry workers }\end{array}$ \\
Pesticide exterminators & - resident use, exterminator use \\
Greenhouse workers and florists & - accidental exposure \\
Office workers & Close proximity to farms \\
Health care workers & Aerial spraying \\
Veterinary employees & Public places \\
Prosectors performing autopsies & Contaminated organ donor \\
Store employees & Suicidal (intentional) poisoning \\
Gulf War veterans & Chemical warfare \\
& \\
\hline
\end{tabular}

$\bar{a}$ Accidental poisoning and suicide poisoning are possible in both occupational and nonoccupational exposures. 
vironment constitutes an occupational exposure. Workers who handle organophosphates directly are at higher risk of exposure than are workers who do not handle pesticides directly. Most occupational exposures to pesticides are through inhalation or dermal exposure, and in some instances by ocular exposure $(2,3)$.

Agricultural workers. Exposure to organophosphate insecticides occurs predominantly on farms $(2,3)$ or in orchards (19), where the insecticides are used for pest control. In the 1990s in the United States some 2.5 million to 5.0 million agricultural workers were exposed to organophosphate insecticides (7). There are about 1.8 million to 2.5 million hired farmworkers in the United States who have come from Mexico, Central America, or South America. During 1997-1998, 77\% of farmworkers in crop agriculture were Mexican-born. One third of migrant farmworkers are in the state of California. In just one of the 58 counties in California, Fresno County, more than 75000 pounds (34 $000 \mathrm{~kg}$ ) of organophosphates were used in agriculture in 1995; these products included chlorpyrifos, diazinon, and malathion (20).

Workers who apply pesticides on crops, livestock, or elsewhere are called pesticide applicators $(2,21)$. They are in direct contact with the chemicals by spraying the insecticide in selected locations. Exposure can also come from mixing, loading, or transporting the chemicals (2). In some situations, exposure can occur from accidental spills of chemicals, leakage, or faulty equipment. Workers exposed to pesticides are usually required to wear personal protective equipment for safety reasons. This equipment includes a mask, protective clothing, gloves, and boots. While preventable, exposure to organophosphates could result from inadequate safety training or poor compliance with safety regulations. Improper practices, such as infrequent changing of clothes, inadequate washing, or eating and smoking while wearing contaminated clothing, increase the probability of exposure to pesticides (22).
Ciesielski and colleagues (21) performed a study on organophosphate exposure and migrant farmworkers in the state of North Carolina in the early 1990s. In comparison to 42 nonfarmworkers, 202 farmworkers had significantly lower RBC ChE activity, which was measured in units (U) per gram (g) of hemoglobin $(\mathrm{Hb})$ in both groups. The RBC ChE activity in the farmworkers was $30.28 \mathrm{U} / \mathrm{g} \mathrm{Hb}$, compared to $32.3 \mathrm{U} / \mathrm{g} \mathrm{Hb}$ in the nonfarmworkers. About $12 \%$ of the farmworkers had very low RBC ChE activity. The cholinergic symptoms reported by farmworkers correlated well with the reported organophosphate exposure.

Accidental poisoning with organophosphates has occurred among agricultural workers. Much of the exposure to pesticides has to do with individual perceptions and knowledge of the risks of pesticide exposure and safety (23). Among migrant farmworkers their methods of handling pesticides and their safety practices reflect their poor knowledge and understanding of the health risks of pesticide exposure (24).

By working close to pesticide applicators, other farm laborers or employees and farm owners who themselves do not handle pesticides may become exposed $(20,25)$. Workers who grow and pick fruits, vegetables, or other crops come into contact with pesticide residues. Aerial spraying of pesticides on farms is another form of exposure for all agricultural workers, including flaggers on the ground, who direct such spraying (25). In the study by Ciesielski et al. (21), $47 \%$ of the agricultural workers reported being sprayed with pesticides or working close to sprayed areas.

With support from the EPA, the United States National Institute for Occupational Health and Safety (NIOSH) has conducted surveillance of pesticiderelated illness in some states (19). The most common agricultural worker illness reported to the California Health Department in 1998-1999 was exposure to organophosphates. Das and colleagues (7) reported that there was more pesticide-related illness among field workers on farms than among agricultural workers who handled pesticides. They also reported that out of 486 farmworkers with pesticiderelated illness, $13.1 \%$ of them reported use of organophosphate insecticides. The main route of entry was by dermal exposure, and their symptoms involved more than one body system.

Pesticide manufacturing. Industrial exposure to organophosphates occurs in chemical plants that produce organophosphate pesticides $(5,10)$. While production workers in the industry are directly exposed to the chemicals, all other employees in the manufacturing plants can be exposed. Workers in these plants face risk situations that are similar to the ones that occur in workers exposed to pesticides on farms.

Burns et al. (26) studied the morbidity of 496 employees exposed to the chlorpyrifos organophosphate in their work in a plant that manufactured the product. In comparison to control subjects, the exposed workers had significantly higher prevalences of diseases of the ear and mastoid process; acute respiratory infections; general signs and symptoms of dizziness, fever, malaise, and fatigue; and ill-defined symptoms of the digestive system. These symptoms were not exclusively attributed to organophosphate exposure.

At an agricultural chemical company in the United States, workers were exposed to another organophosphate, mevinphos (27). The exposure was primarily from the packaging of the chemical in the hopper/bagging operation. Four out of nine workers reported some form of illness, and they were treated at a hospital. Their cholinesterase levels were $50 \%$ below their baseline levels. The incidents were investigated by a team from the United States Occupational Safety and Health Administration, which confirmed organophosphate toxicity as a result of the occupational exposure to mevinphos.

Exterminators who use pesticides. Exterminators who use pesticides are a major group of workers with occupational exposure to organophosphates. 
These workers apply pesticides in public places and in private residential homes, often to control termites (28, 29). Pest control services have also been extended to lawn care and tree service in the United States (22).

In the state of New York, there were 13417 pesticide applicators who were certified to work on residential and commercial properties in 1996 (22). In a review of suspected and confirmed pesticide poisonings of lawn care and tree service applicators that were reported to the New York State Pesticide Poisoning Registry from 1990 to 1993, 39 cases were identified, of which 28 satisfied the criteria for a suspected or confirmed poisoning. Twenty-four workers had reported symptoms. The most common pesticides applied were organophosphates, reported by $71 \%$ of the workers.

In a survey of 191 pesticide applicators in the state of North Carolina who had worked for a median of 1.8 years applying organophosphates against termites and other pests, the average urinary chlorpyrifos metabolite for 65 of the recently exposed applicators was far higher than that of the general United States population: $629.5 \mu \mathrm{g} / \mathrm{L}$ vs. $4.5 \mu \mathrm{g} / \mathrm{L}$ (29). In that same North Carolina area, $60 \%$ of the pest control companies reported using pesticides containing chlorpyrifos.

Greenhouse workers and florists. Pesticide exposure is also known among greenhouse workers. Their work includes the use of pesticides on flowers, other plants, and foliage (10). Fumigant pesticides are considered a potential health risk to employees of greenhouses. For example, in one case in the state of Texas in 1995 the worker had used sulfotepp as a fumigant for flowers and had become ill during the fumigation despite wearing personal protective equipment (30).

Office workers. Workers in offices are occasionally exposed to pesticides applied by exterminators $(25,26)$. While unintended, it is considered a workrelated exposure because of the introduction of a hazardous chemical into a work environment, even though the pesticide application is not a part of the office worker's job description. The frequency of exposure to pesticides among office workers is not as high as it is in agricultural workers or chemical industry employees, but any single or unusual exposure to pesticides among workers carries a potential health risk. The specific risk would depend on the office environment, the concentration of pesticide used, and whether or not office workers were present at the time of application.

Hodgson (31) described an instance where five workers in an office developed symptoms compatible with organophosphate intoxication after an application of chlorpyrifos. Even though the workers' initial ChE activity did not correlate with the symptoms reported, their RBC ChE levels increased significantly over the 3 months following exposure.

Health care worker exposure (nosocomial poisoning). Heath care workers in hospital emergency departments are at risk of exposure to organophosphate pesticides by secondary contamination from patients who have acute organophosphate poisoning. The health care workers' exposure occurs by their close contact with and handling of the patient. In a hospital in the state of Georgia in 2000, three emergency department workers became ill after managing a patient who had intentionally ingested an organophosphate insecticide (32). All three workers subsequently developed signs and symptoms of acute organophosphate poisoning, for which they were treated. The importance of this case report is the risk of organophosphate exposure to the health care workers from the patient and from the workers' not wearing protective clothing and gloves in the situation. Health care workers should be aware of and guard against any form of chemical exposure from direct contact with contaminated patients.

Veterinary exposure. Veterinary employees can be exposed to pesticides from the chemicals applied to animals for pest control (10). In one case, a vet- erinary technician was exposed while opening a sealed package of organophosphate insecticide. This exposure resulted in cholinergic symptoms of acute organophosphate poisoning such as headache, nausea, vomiting, diarrhea, and difficulty in breathing; the symptoms were treated in a hospital (33).

In another case a pet groomer who was not wearing any protective clothing was exposed to phosmet while washing a dog in a tub (34). The organophosphate was being used to destroy fleas on the dog. The 35-year-old female worker developed severe cholinergic symptoms an hour after the exposure. She immediately went to a hospital emergency department. However, her ChE levels were within normal limits, and she recovered without any treatment. She had used organophosphates to wash the animal on several occasions during the preceding year, without wearing any protective clothing.

Autopsy of exposed patients. Prosectors are at risk of exposure when they perform autopsies of patients who have been exposed to organophosphate insecticides. Handling bodies contaminated with such chemicals is a form of exposure, which can be prevented by using proper autopsy procedures and protective equipment and clothing (35).

Exposure in a retail store. Physicians in California reported four incidents of organophosphate exposure following spills in retail stores in 1986, where the store employees tried to clean up the spills without wearing protective clothing (28). While not common, this kind of exposure is clearly occupational in nature since the employees' exposure was at their workplace.

Gulf War veterans. The exposure to organophosphates among United States military servicemen during the Gulf War of 1990-1991 is considered to be an occupational exposure. During that conflict some Allied troops were possibly exposed to organophosphate nerve poisons such as sarin and cyclosarin as a result of the destruction 
of Iraqi munitions at Khamisiyah (36). Some 2900 United States Gulf War veterans reported symptoms suggestive of low-level sarin exposure 9 years after that demolition event. It was concluded that over 100000 United States servicemen in Iraq at that time were possibly exposed to low levels of sarin and cyclosarin by the Khamisiyah incident $(37,38)$. The bombing of an ammunition storage facility at Muhammadiyat, Iraq, may have exposed 76 United States Special Forces troops to low levels of the organophosphate nerve agents (38).

\section{Environmental or nonoccupational exposures}

Environmental or nonoccupational exposure to organophosphates in individuals occurs in any place where the exposure to pesticides is not a result of the person's job or occupation. There are numerous situations where exposure to organophosphates occurs in the general population in places other than workplaces (16). Exposure to organophosphates can also be paraoccupational, such as from living close to a workplace that uses pesticides or when workers bring home contaminated articles and thus expose their family members (14).

Environmental exposure to organophosphates also carries the risks of morbidity and mortality. The EPA's Pesticide Incident Monitoring System showed that incidents of organophosphate poisoning from nonoccupational exposures were highly prevalent during the period of 1966 to 1980 (16). A review of pesticide mortality in the United States for the 1979-1998 period reported that out of 364 deaths from pesticide poisoning, $28 \%$ were a result of accidental exposures to organophosphate insecticides (17).

Residential exposure. The use of organophosphates in private homes forms a large part of the nonoccupational exposures in the general population in the United States (16). Domestic use of pesticides is common: $80 \%-90 \%$ of
American households use pesticides in the home (39). Organophosphate insecticides are used for killing bugs in and around the house and in the garden $(2,40)$. In 2000 the National Center for Food and Agricultural Policy, a private nonprofit research organization based in Washington, D.C., estimated that up to 3 million pounds (1.4 million $\mathrm{kg}$ ) of chlorpyrifos was being used in the home-and-garden market each year. Chlorpyrifos is used to destroy cockroaches, fleas, spiders, and flies indoors as well as mosquitoes, ticks, bees, and poison ivy outdoors (41).

In one case, a 36-year-old female was taken to the emergency department of a hospital with symptoms of acute organophosphate poisoning (42). The patient had an odor of pesticide; she admitted to having sprayed diazinon over her rose bushes earlier that day. She also sprayed a higher concentration of pesticide around the base of her home to prevent insect infestation in the house. During the application, some of the diazinon spilled onto her skin and shirt, which she had not changed. This was a clear case of acute organophosphate poisoning from domestic use of diazinon.

While not very common, accidental poisoning with organophosphates in the home is a possibility from house or garden use of pesticides. Exposure is likely to occur from spills, improper use, or poor storage. Situations arise where people who do not know they are handling pesticides are exposed. This can happen when a pesticide label is misread or a pesticide container is opened without reading the label. Exposure can also come from mishandling, such as by transferring pesticides from their original packages into household containers, and from the lack of compliance with instructions or safety warning labels (41). Adults can be exposed to high doses of organophosphates by accident. A 46year-old man in the city of Philadelphia was accidentally exposed to organophosphates, from which he developed a florid acute respiratory distress syndrome, with markedly depressed serum and RBC ChE levels, together with acute cholinergic signs and symptoms. The patient died 3 days later in the hospital despite maximum ventilatory support (43).

The extensive use of organophosphates in residential areas constitutes a major form of exposure in the general population. When exterminators spray private homes or apartment buildings with pesticides, the residents can be exposed $(28,39)$. Steenland and colleagues (29) reported that houses and lawns in the United States receive approximately 20 million chlorpyrifos treatments annually and that $82 \%$ of adults in the country have detectable levels of chlorpyrifos metabolites in their urine. Organophosphate pesticides are present in the air in homes, so exposure can occur from inhalation $(39,44)$.

In northern Manhattan and the South Bronx, which are two sections of New York City, 85\% of 314 AfricanAmerican women and Dominican immigrant women reported the use of pest control measures in their homes during their pregnancy (39). Thirtyfive percent of the women reported the spraying of pesticides in their homes by an exterminator.

Organophosphates also settle on various objects and items in a home, thereby increasing the risk of exposure. The organophosphates are present in house dust and on floors, carpets, toys, dinnerware, and tables and other furniture $(41,45)$. Exposure occurs by inhalation or dermal contact. The close contact with the pesticide could also result in ingestion of the chemical by consumption of contaminated foods, including fruits and vegetables and water and other beverages. Diet is a significant source of organophosphate exposure $(45,46)$.

A survey in the state of Washington found that contaminated fresh produce and fruit juice were a means of exposure in consumers (45). Exposure to organophosphates could occur when consumers failed to adequately wash fruits and vegetables that had been sprayed while growing. In the state of Maryland a survey of pesticides in foods from September 1995 to September 1996 showed positive re- 
sults for the presence of organophosphates. Chlorpyrifos was detected in $38.3 \%$ of solid food samples and malathion in $75.2 \%$ of duplicate plates of food samples from 75 subjects (46).

Children are an extremely vulnerable, high-risk group for pesticide exposure $(45,46)$. In fact, the Food Quality Protection Act, legislation that was approved in the United States in 1996, requires the EPA to place particular emphasis on assessing potential risk from pesticides to infants and children (47). In the metropolitan area of Seattle, Washington, during the spring and fall of 1998, of 110 children from different families, nearly all the children had metabolites of organophosphate insecticides present in their urine (45). Much of the exposure was attributed to a contaminated diet. However, the children of parents who reported using pesticides in the garden had higher concentrations of organophosphate metabolites in their urine than did the children of families who had not reported the use of pesticides in their gardens. Children can also be exposed to organophosphates in the home if the pesticides are left within their reach; ingesting the chemicals could result in severe acute organophosphate poisoning (41).

Agricultural worker take-home exposure (paraoccupational). Agricultural workers who are exposed to pesticides in their work can also expose persons at home if they return home with contaminated clothing and then have close contact with their children and other family members and with household items. Children of agricultural workers can face an increased risk of exposure to pesticides $(14,48)$. A study by Fenske et al. (45) in the state of Washington showed that, in comparison to children from reference families, the children of agricultural families had a higher exposure to organophosphates, as indicated by higher levels of metabolites of organophosphate insecticides in their urine. Levels of organophosphates in house dust were also high in the homes of the agricultural families.
Close proximity to farms. Exposure can often occur when organophosphate pesticides applied on farms drift into surrounding areas where people live. This form of exposure is termed the "farm proximity pathway" (45). While the nearby residents' exposure may not be to the extent it is among agricultural workers, their proximity to an organophosphate source still puts them at risk.

The study in the state of Washington by Fenske et al. (45), which was mentioned above, showed that children of non-agricultural workers living close to farms (up to $200 \mathrm{ft}(61 \mathrm{~m})$ ) had detectable levels of dimethyl organophosphate urinary metabolites, similar to that in the children of agricultural workers. Those children of non-agricultural workers had been exposed to organophosphates that included azinphos-methyl, phosmet, chlorpyrifos, and ethyl parathion (45).

Aerial spraying. The extensive spraying of pesticides from aircraft over residential areas can be a source of exposure in the general population if the residents of the sprayed areas breathe in air that contains the organophosphates (2). The aerial spraying of a malathion bait to eradicate the Mediterranean fruit fly covered a large urban area in Santa Clara County, California, in 1981. This project, carried out by the United States Department of Agriculture, caused much alarm among the public. However, a subsequent survey showed that there was no detectable increase in acute morbidity in the area's population (49). In contrast, with the aerial spraying of a malathion bait in the Mediterranean Fruit Fly Eradication Program in the state of Florida in 1998 there were 123 reports of probable or possible pesticide-related cases of illness among the general population (50).

During 1999-2000 the first outbreak of West Nile virus in the United States led to the aerial spraying of pesticides over New York City to combat the virus-transmitting mosquitoes. Organophosphates (mainly malathion) were also used as larvicides to prevent disease transmission. The use of organophosphates against mosquitoes carrying the West Nile virus has promoted public and health-professional awareness of the disease $(51,52)$.

Exposure in public places. Exposure to pesticides in public places is an unexpected, unintentional, nonoccupational form of exposure among the general public (28). For example, people can be exposed to organophosphate insecticides applied by exterminators in such places as public restrooms, restaurants, hotels, schools, churches, business offices, apartment buildings, grocery stores, and hospitals $(28,53)$. Other such sites are public gardens, parks, sidewalks with trees or other plants, gardens outside office buildings, malls, and even entire municipalities. This form of exposure may be minor compared to other situations described above.

Exposed organ donors. The mother of a 17-year-old male in the state of Georgia found him having seizures, with an empty container of malathion at his bedside. He was hospitalized immediately and treated for acute organophosphate poisoning (54). However, the patient developed aspiration pneumonia and became comatose. Five days after entering the hospital, the patient was declared brain dead, and his organs were removed. His liver and kidneys were successfully transplanted. In spite of the successful transplantation in this case, the authors of the article pointed out that poisoned organ donors are potential sources of organophosphate exposure for organ recipients.

Suicide (intentional) poisoning. Most of the suicide cases involving organophosphate poisoning happen in developing countries, particularly in Sri Lanka, and much less so in the United States (5). The Toxic Exposure Surveillance System of the American Association of Poison Control Centers has information on fatal exposures to or- 
ganophosphate pesticides in the United States. Four cases of suicide poisoning occurred during the year 2000: one person ingested diazinon, and three people ingested malathion (15).

The case of the 17-year-old male whose liver and kidneys were transplanted, as described above, appears to be a suicidal poisoning with malathion (54). In the hospital the patient exhibited symptoms consistent with acute organophosphate poisoning, and his initial plasma ChE activity was 1433 international units per liter (IU/L), vs. the normal level of 7500 to $14600 \mathrm{IU} / \mathrm{L}$.

In Texas an 80-year-old woman committed suicide by ingesting malathion mixed with fruit juice (55). She developed a severe cholinergic crisis; her condition deteriorated, with respiratory and renal failure, and she died 12 days later. The antemortem blood level of malathion was extremely high, $23.9 \mathrm{mg} / \mathrm{L}$.

Chemical warfare. The threat of terrorism is a serious public health concern in many countries around the world, with especially increased awareness in the United States (56). Since some organophosphates are nerve agents, they could be used by terrorists as chemical warfare agents (18). These substances include tabun, sarin, soman, VX, and GF. The "G" series were labeled as such because of their origin in Germany, while the " $\mathrm{V}$ " series represent venomous poisons (57). These agents inhibit ChE activity and result in widespread manifestations of peripheral and central nervous system dysfunction, which could be fatal (18).

An outbreak of sarin poisoning occurred in a subway station in Tokyo in 1995, caused by the dispersal of the nerve agent by a terrorist group (58). On the day of the disaster, 641 victims were seen at the St. Luke's International Hospital in Tokyo. All the victims suffered from severe cholinergic symptoms, with miosis, headache, dyspnea, nausea, ocular pain, blurred vision, coughing, muscle weakness, and agitation. Some patients arrived with cardiopulmonary or respiratory arrest, and there were two deaths.
A South African religious leader was allegedly a victim of poisoning with an organophosphate over the course of a trip from South Africa to the United States via Namibia in 1989 (59). On his arrival in Namibia, he was seen in a hospital, suffering from abdominal pain, nausea, vomiting, diarrhea, and extreme weakness. His symptoms settled within 48 hours, after which he left for the United States. Shortly after he arrived in the United States, his symptoms reappeared and he was admitted to a hospital. In the hospital he had respiratory arrest requiring intubation. He recovered, was discharged, and then was readmitted within 24 hours with profound anxiety, confusion, hyperventilation, respiratory alkalosis, and hypophosphatemia. A diagnosis of organophosphate poisoning was confirmed by low ChE activity. It was later concluded that he had been exposed to an organophosphate that had been placed in his suitcase by a member of a South African military unit.

\section{BIOLOGICAL MONITORING OF CHOLINESTERASES}

Biological monitoring of organophosphate pesticides includes a method of surveillance for assessing exposure by measuring $\mathrm{ChE}$ activity in RBCs and serum $(2,3)$. This is applied mainly to the workers exposed to organophosphates. However, ChE activity is measured to assess acute organophosphate toxicity from any exposure, including the nonoccupational situations, since ChE depression is diagnostic of organophosphate toxicity. The two enzymes measured for biological monitoring are RBC ChE (EC 3.1.1.7 under the enzyme nomenclature system of the International Union of Biochemistry and Molecular Biology) and serum or pseudo ChE (EC 3.1.1.8). Both enzymes should be measured; the findings of both tests are significant and useful in assessing organophosphate toxicity $(2,3)$.

There are several methods used for analyzing serum and RBC ChE ac- tivity, including the electrometric method (of Michel), $\mathrm{pH}$ stat method (titrimetric), colorimetric method (of Ellman), and, more recently, the gas chromatographic method (of Cranmer) (2). A portable, battery-operated test kit is available to use in the field; it uses the colorimetric (Ellman) method to measure ChE activity (60). McConnell et al. (61) used the test kit to measure RBC ChE activity in workers in a Mexican pesticide formulation plant.

The serum ChE enzyme is produced in the liver, and it is a more reliable measure for detecting acute organophosphate poisoning than is the RBC ChE. Serum ChE activity is depressed by organophosphates very rapidly and it is also restored to normal levels quickly $(2,3)$. In the acute phase of organophosphate poisoning, serum ChE activity is usually depressed within a few hours to a few days. About 3\% of the population has a genetic variation manifested by a serum ChE deficiency $(2,3)$. Pregnancy, acute or chronic inflammatory conditions, malnutrition, and liver disease are conditions that also affect serum $\mathrm{ChE}$ activity. The depression of $\mathrm{ChE}$ caused by these conditions is not as great as that caused by organophosphate insecticides $(2,3)$.

The $\mathrm{RBC} C \mathrm{ChE}$, which is present in nervous tissue and the RBCs, is the preferred measure for organophosphate toxicity $(2,5)$. It is depressed less rapidly by organophosphate insecticides than is true for the serum ChE. During the acute phase of organophosphate poisoning, the $\mathrm{RBC} \mathrm{ChE}$ activity is usually not depressed. It takes a few hours to a few days for RBC ChE activity to decrease, and about 60 to 90 days for the depressed RBC ChE levels to be restored to normal. A person with symptoms of organophosphate poisoning may not necessarily have low RBC ChE activity; it does not always correlate with acute cholinergic symptoms.

Workers exposed to organophosphate insecticides should ideally have a preemployment or preexposure (baseline) ChE measurement. This measurement is compared with a 
TABLE 3. Guidelines for cholinesterase (ChE) levels in relation to exposure and symptoms of organophosphate toxicity

\begin{tabular}{ll}
\hline \multicolumn{1}{c}{ ChE level (activity) } & \multicolumn{1}{c}{ Feature } \\
\hline $75 \%$ to $100 \%$ of baseline & Normal, asymptomatic \\
$50 \%$ of baseline & Symptoms present \\
$20 \%$ to $50 \%$ of baseline & Mild exposure, minimal symptoms \\
$10 \%$ to $20 \%$ of baseline & Moderate exposure, muscle fasciculations, myosis \\
$0 \%$ to $10 \%$ of baseline & Severe poisoning, life-threatening symptoms, acute \\
& cholinergic crisis \\
\hline
\end{tabular}

Source: Sullivan JB Jr., Blose J (2) and Schenker MB, Albertson TE, Saiki CL (3).

postexposure $\mathrm{ChE}$ level to determine the extent of organophosphate toxicity. Table 3 describes the levels of $\mathrm{ChE}$ inhibition or depression in relation to organophosphate toxicity. A preexposure or baseline ChE level for an individual represents normal ChE activity. This level can vary widely from person to person. A 50\% reduction in $\mathrm{ChE}$ activity from the baseline may result in acute cholinergic or toxic symptoms of organophosphate exposure $(2,3)$. The California Health Services Department has set threshold values of ChE activity for removal of workers from continued exposure to organophosphates. For RBC ChE activity it is set at $60 \%$ of the baseline, and for serum ChE it is $50 \%$ of baseline (62). Workers are allowed to return to work once their ChE levels reach $75 \%$ of their baseline levels (3).

In many cases when the baseline values are not known, laboratory reference ranges may be used. These values differ among laboratories, and the range is very wide, with a $300 \%$ spread (5). People with a reduction in their ChE activity of more than 50\% may have toxic symptoms of organophosphate exposure even though the value may still be within the reference range (that is, above the lower limit) (Figure 1). This means that some people have a higher baseline ChE level compared to other persons. Workers with long-term exposure to organophosphates have a chronically low RBC ChE activity, yielding a falsely low baseline level $(2,3)$. Therefore, the reference range would not be applicable in such cases, since the baseline
ChE levels might be below $75 \%$ of the upper limit of the reference range. able for exposed workers, a series of ChE measurements over an interval of
When a baseline level is not avail-

2 to 3 months after removal from organophosphate exposure would serve to make a comparison to the initial ChE activity. Any ChE measurement done during a period of exposure to organophosphates would be the starting point. Subsequent ChE measurements done, after the worker is removed from the exposure, are compared to the $\mathrm{ChE}$ activity during organophosphate exposure. A gradual increase in ChE activity over 2 to 3 months would indicate that the worker had been exposed to organophosphates (30) (Figure 2).

The carbamate group of pesticides are also anticholinesterases, or ChE inhibitors. The carbamate pesticides inhibit ChE activity by a reversible spontaneous hydrolysis and carbamy-

FIGURE 1. Illustration of cholinesterase (ChE) depression that is greater than $50 \%$ in a worker but that still lies within the laboratory reference range

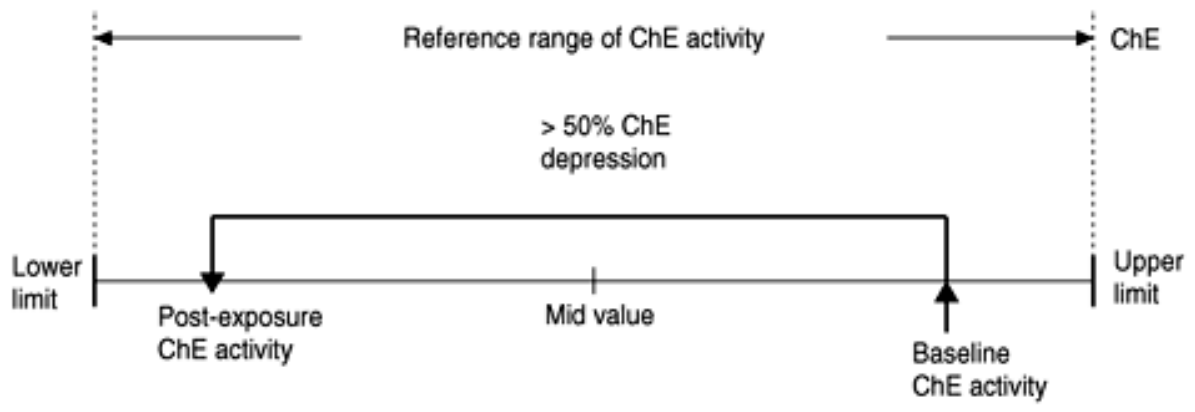

FIGURE 2. Increase in red blood cell (RBC) cholinesterase (ChE) activity after removal of a worker from organophosphate exposure

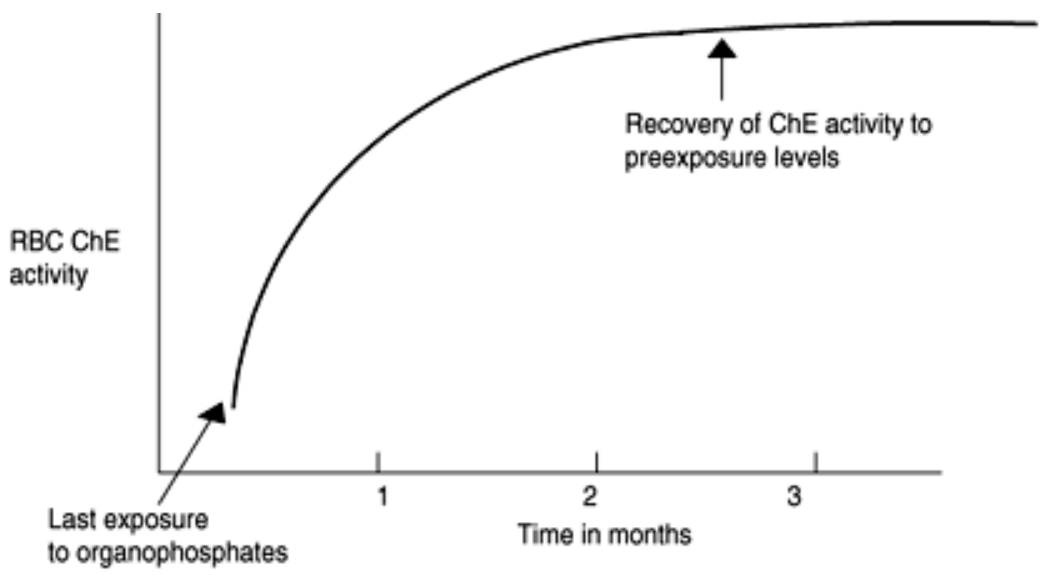


lation of acetylcholinesterase, with a rapid onset of action. The clinical picture of carbamate poisoning is very similar to that of organophosphate toxicity, though less severe in nature. The carbamate symptoms are of a shorter duration, and there are fewer effects on the CNS. ChE activity in workers exposed to carbamate pesticides is as low as with organophosphate toxicity. This makes it difficult to distinguish between organophosphate and carbamate toxicity based on ChE measurements, especially when workers are exposed to both groups of pesticides $(2,5)$.

\section{REGULATION OF PESTICIDES}

Internationally, the World Health Organization (WHO) has a program that promotes and coordinates policies, strategies, and guidelines for the use of pesticides in public health, including in the areas of pesticide specifications, safety issues, and effectiveness (63). In the United States, regulation of pesticides started in 1947 with the Federal Insecticide, Fungicide, and Rodenticide Act (FIFRA), which advocated the manufacture, use, and distribution of pesticides. The FIFRA was amended several times before 1970, when the EPA became responsible for pesticide regulation and registration $(1,2)$. The Federal Food Drug and Cosmetic Act (FFDCA) allows the EPA to establish, modify, or revoke acceptable pesticide residue levels in foods. The United States Food and Drug Administration (FDA) ensures that the EPA-established pesticide residue levels are not exceeded in foods.

In 1996, the United States Congress amended the FIFRA and FFDCA, with the passage of the Food Quality Protection Act (FQPA) (47). The FQPA established a new safety standard for pesticides in food that is intended to be more consistent and to offer better protections for the public. A major feature of the FQPA is the emphasis that it places on children's health, including protecting them from pesticide exposure. In some situations the FQPA applies an additional 10 -fold safety factor for children as compared to adults (64).

The Occupational Safety and Health Administration (OSHA) of the United States regulates pesticide exposure among agricultural workers in order to prevent pesticide-related illness. OSHA's Field Sanitation Standard specifies the requirements for the provision of potable water, toilets, and washing facilities on farms, in part as a way to reduce pesticide exposure. Since 1992 the EPA's Worker Protection Standard has aimed at reducing the risk of pesticide poisonings and injuries among agricultural workers. This EPA regulation includes requirements for safety training, notification of pesticide poisonings, use of personal protective equipment, restricted entry intervals following pesticide application, decontamination supplies, and emergency medical assistance (7). The EPA requires that restricted organophosphate pesticides be used only under the direct supervision of certified pesticide applicators who have had appropriate training so as to prevent any harm to themselves, to others, and to the environment (4).

The California Health Services Department has a policy that requires medical supervision and regular monitoring of ChE activity in workers exposed to cholinesterase-inhibiting pesticides (62). The California policy requires preexposure and postexposure ChE testing to assess organophosphate toxicity and to determine whether workers should be removed from the exposure.

The EPA has given serious consideration to the potential health risk of chlorpyrifos exposure in children. The use of this pesticide is restricted in terms of its use indoors as well as outdoors in homes and public places (41).

Regulation of pesticides has also progressed in other nations of the Western Hemisphere. For example, at the XVI Special Meeting of the Health Sector of Central America and the Dominican Republic, held in Tegucigalpa, Honduras, in September 2000, the ministers of health who met there ratified an agreement on restrictions and prohibitions for pesticides, focus- ing on the 12 pesticides that are responsible for the greatest morbidity and mortality from acute pesticide poisoning in Central America (6).

\section{DISCUSSION}

Organophosphate exposure is highly prevalent in developing countries. In the United States the EPA has restricted many organophosphate insecticides because of their potential hazardous effects on human health and the environment (4). There are various circumstances where people may be exposed to organophosphates, but there is a higher risk to workers through occupational exposure than there is to the general population through environmental exposure. Nevertheless, widespread residential exposure to organophosphates does pose some level of risk for a large segment of the general population in the United States.

Organophosphate exposures can produce acute toxicity, resulting in high morbidity and even death. The toxicity of an organophosphate is determined by the exposure level of the organophosphate in the environment, the dose absorbed, and the level of $\mathrm{ChE}$ depression in an individual. The pesticide-related illness that people suffer from chronic exposure to low to moderate doses of organophosphates is a public health concern. This is more of an occupational health issue and is most relevant to agricultural workers and workers in the pesticide manufacturing industry. The long-term effects of organophosphates are of interest to researchers and scientists. Chronic neurological sequelae of toxic exposure to organophosphates have been reported. Further studies are needed to determine whether chronic low-dose exposure to organophosphates results in neurological and neurobehavioral effects in the exposed population.

Persons from Latin America who are employed as migrant farmworkers in the United States are an important population with occupational pesticide exposure. Therefore, more migrant workers should be encouraged to utilize the Migrant Health Program, 
which operates as part of the Bureau of Primary Health Care of the Health Resources Services Administration of the United States Department of Health and Human Services (7). The Migrant Health Program provides comprehensive primary care and preventive health services to migrant workers and their families throughout the United States. Since farmworkers are at high risk of organophosphate exposure, enforcement of pesticide safety regulations for workers on farms is needed. Good occupational health practices involve such tasks as worker education on the safe use of pesticides, supervision of pesticide applications, wearing of personal protective equipment, safety training, and strict compliance with pesticide regulations (65). As a part of health education, simple methods can be applied to better protect farmworkers from pesticide exposure and to improve their knowledge of the hazards of pesticide exposure. Selfexplanatory signs or posters describing pesticide exposure and health risks should be placed at appropriate sites on farms. Given the high Latin American migrant farmworker population, relevant information on pesticides should be presented in Spanish in addition to English.

Occupational health services for farmworkers should be easily accessible, most importantly antidotes for organophosphate poisoning, either atropine or pralidoxime (7). Washing facilities and emergency first aid care should also be provided. In cases where there are no health personnel or health services available on site, arrangements should be made for transporting any exposed worker to the nearest hospital for emergency care (25). This service is critical for severe, life-threatening cases of organophosphate poisoning with a cholinergic crisis.

In the United States, cases of acute organophosphate poisoning and pesticide-related illnesses are considered to be notifiable conditions that health care providers must report to local and state authorities. In addition, workers in the United States have a legal right to workers' compensation payments for any injury or ill health caused by their work. This would be true, for example, for agricultural workers who suffer acute organophosphate poisoning in their work. A physician examining a person who has been exposed to a pesticide should undertake the examination in an organized and methodical manner in order to ensure appropriate treatment as well as to avoid fraudulent compensation claims (25).

The California Health Services Department has implemented certain policies with regard to medical monitoring for pesticide-related illness and $\mathrm{ChE}$ testing of workers. The regular biological monitoring of ChE activity in agricultural workers that is done in California could be a model for other states (62). This system protects workers from toxic exposure by properly removing them from further organophosphate exposure and by only allowing their return to the fields at an appropriate time. A more practical approach would be to use a portable kit to measure RBC ChE activity. It is convenient, reliable, and easier to use in the field than sending blood samples to a laboratory for diagnosis. It may also be a more cost-effective method for monitoring a large workforce for organophosphate exposure. In addition to biological monitoring for $\mathrm{ChE}$ depression in workers, environmental monitoring of organophosphates with measurements in air, water, or soil by industrial hygienists on farms would be useful (26). A major part of health care for agricultural workers is the surveillance of chronic pesticide-related illness in the majority of workers with chronic exposure to organophosphates. This requires regular monitoring of symptoms of organophosphate exposure reported by workers, to be followed by appropriate health care management (7). Any action taken to reduce pesticide-related illness would improve the well-being and general health of agricultural workers, which should be among the goals of any occupational health program.

Principles and rules for health and safety for organophosphate exposure are applicable to both workers in agriculture and workers in the organophosphate manufacturing industry.
Based on the nature of their jobs, workers in those two sectors may face differences in their potential exposure to organophosphates. Both groups of workers are at high risk of exposure, so taking appropriate, adequate health and safety precautions is essential. Organizing health and safety programs to educate workers and making provisions for emergency health care for cases of acute pesticide poisoning are both important. Another component of these efforts are the material safety data sheets that pesticide manufacturers provide. These sheets explain possible toxic effects and specific precautions to be taken. The sheets are available to workers and are placed at appropriate, easily visible locations in workplaces (25). On farms in the United States, farm owners are responsible for providing information on hazardous pesticides to their workers.

While the risks of organophosphate exposure are highest for agricultural workers and for workers in the chemical industry, other workers need to be protected as well. For example, exterminators using pesticides are vulnerable to toxic exposures. Educating workers on pesticide toxicity is a very important tool for preventing toxic exposures (7). The most important concern in any occupational exposure to organophosphates is the single highdose exposure, which could result in an acute cholinergic crisis. Care should be exercised in order to avoid a critical situation, with respiratory arrest or CNS depression in exposed employees. Workers should be removed from an area where organophosphates are applied in their workplace, and they should be permitted to return only when they are safe from hazardous pesticide exposure. This can be particularly true for office workers, who are not accustomed to or generally exposed to pesticides in the workplace (25).

Situations of occupational and environmental exposure to organophosphates differ in terms of the frequency of pesticide use, the level of awareness and familiarity with pesticide use, and whether or not there is a system for pesticide safety. In nonoccupational 
situations the exposure is mainly circumstantial or accidental, without any protection for people who are exposed. It is evident from the scientific literature that exposure to organophosphates can affect people who come into direct or indirect contact with the chemicals in any situation where the pesticides are available or are introduced. Thus, the general environmental exposure to organophosphates may be lower in intensity than is true for occupational exposure, but that environmental exposure may affect a larger segment of the population.

Domestic use of organophosphates in the United States is frequent and widespread and presents a serious public health concern. Much of the domestic use of organophosphates by housewives or other household members is unsupervised. In addition, there is often improper storage of the substances, little use of personal protection equipment or clothing, and poor knowledge of organophosphate toxicity. Residents using pesticides in their homes may not read instruction labels properly, or they may not realize the seriousness of the warnings of organophosphate toxicity. Further, the extensive use of organophosphates by pesticide applicators in homes exposes a large population to hazardous chemicals. For safety, residents should be temporarily evacuated from the affected houses or surroundings.

The presence of organophosphates in the diet is a major source of exposure. People consuming contaminated food and beverages are not aware of this exposure, nor are the levels of contamination known. The full implementation of FQPA will eventually reduce such exposures among the general population and help to protect human health.

The most vulnerable of all groups are children and infants, who are at a very high risk of organophosphate exposure. Children may not understand the risk of pesticide exposures and can be accidentally exposed in the home. Much has to do with their activities and behavior, including easy access to pesticides stored at home, contact with pesticide containers or contaminated articles, and their diet. Organophosphate toxicity in children could require emergency treatment and care. The extent of the organophosphate toxicity in children would be determined by their general health, nutritional status, metabolic rate, immune status, and the dose of exposure (44). Children may not sustain the impact of a toxic exposure to organophosphates as easily as adults would. Extra care should be taken when children are exposed to pesticides, especially children of parents who are exposed to such chemicals at work. Such secondary contamination increases the health risks for children.

Organophosphates can be transferred from a pregnant female to the fetus via placental circulation, as has been shown experimentally in rats (66). In utero exposure to organophosphates will later affect the newborn and the growing infant. One study (67) has shown that chlorpyrifos possibly affected four children of mothers who had been exposed to the insecticide by their occupation during their pregnancies. The children were born with extensive and unusual patterns of birth defects affecting the brain, eyes, ears, palate, teeth, heart, nipples, and genitalia. All four children also suffered from mental and growth retardation. Maternal exposure to organophosphates is likely to affect the acetylcholinesterase present in fetal brains as well as the fetal neural function (68). Organophosphate exposure in fetuses, neonates, and infants is an area of developmental toxicology that requires further research. However, the EPA has already taken serious steps to reduce chlorpyrifos exposure in children (40). That action was taken based on animal studies that showed that chlorpyrifos causes higher systemic toxicity in neonates than in adults.

Some organophosphate compounds considered to be nerve agents were apparently released in the Gulf War, affecting United States military personnel. This group of organophosphate chemicals is very dangerous, and they could be used for terrorist attacks. The incident in the Tokyo subway station, which is described earlier in this article, is a likely preview of such a situation. The nerve poisons could have adverse effects on a large group of people if applied as chemical warfare agents. Bioterrorism is a threat to all humanity (56). Western nations are on a higher level of alert for such attacks and have tightened their security measures. It is important that people be made aware of the possibility of nerve agents being used in chemical warfare. In the event that these agents are used against any population, the destruction will be evident from a widespread cholinergic crisis. Large numbers of people will be severely affected, with serious illness and fatalities. This will have a major impact on emergency health care resources, facilities, and personnel, including physicians, nurses, nurses' aides, clinical pathologists, and laboratory technicians (18). Exposed victims will suffer long-term effects from the toxic nerve agent exposure, and there will also be psychological and traumatic effects on the general population. Such an event will involve government security personnel, firefighters, state and local authorities, police officers, and military personnel. Health authorities, government officials, local and state authorities, and health care professionals have a responsibility to alert and educate the public now as well as to provide care and services in the event of any chemical warfare.

The treatment of patients with acute organophosphate poisoning is an important part in the health care of pesticide toxicity. Any person exposed to an organophosphate insecticide faces the risk of a significant $\mathrm{ChE}$ depression, resulting in an acute cholinergic crisis. However, with environmental exposures in the general population, there may be some delay in receiving emergency care, and physicians may not be aware of the exposure to organophosphates unless they are informed by the patient or the person accompanying the patient. Patients with acute organophosphate toxicity may be brought into the emergency room unconscious or in a comatose state. Therefore, it is critical for physicians to receive a proper history of exposure in order to make a diagnosis 
and select appropriate treatment (25). The laboratory finding of depressed ChE activity confirms the diagnosis of organophosphate poisoning. Therefore, it is vital that this investigation be done in emergency situations. The critical steps in these cases are the clinical diagnosis of organophosphate toxicity, the immediate treatment of poisoning, and appropriate supportive care and management of the patient.

Organophosphate exposure is a major public health issue in the United States, Central and South America, Africa, and Asia. Despite strict regulatory laws and restrictions by the EPA, organophosphate exposure is still highly prevalent in the United States. Various situations of nonoccupational exposure to organophosphates have been described in this article. Some of the circumstances are unlikely to occur, but are nevertheless clearly cases of exposure to organophosphates. No matter how uncommon or infrequent the situation might be, organophosphate exposure is a health risk for the general population. It is important that public health professionals be more informed of the potential effects of organophosphate exposure. Agricultural workers, especially migrant workers from Latin America, are more exposed to organophosphate pesticides than is the general population in the United States. In order to prevent the damaging effects of organophosphates on human health and the environment, national regulations in the United States should remain in place and should be strictly followed. In addition, policies and regulations on pesticide exposure, health, and safety should be implemented at the state and local government level.

Employers whose workers are exposed to organophosphate insecticides have a special responsibility. Ensuring the safe use of pesticides and preventing toxic exposure among workers requires efficient administration and management in the workplace. Rules and regulations to prevent organophosphate toxicity should be understood and administered by managers, administrators, safety officers, supervisors, team leaders, and union officials. Workers should also participate in controlling pesticide exposure. Good supervision in combination with educating employees on the consequences of hazardous exposures will help workers put the principles of safe pesticide use into practice.

Since environmental exposure to organophosphates is highly prevalent in the United States, there is an increasing need to protect the general population from pesticide toxicity. Federal, state, and local health author- ities are key in ensuring public safety and providing protection from toxic pesticide exposure. Local health departments, educational institutions, scientists, teachers, health care professionals, public health professionals, and other concerned persons are key to promoting health education and alerting the public to the effects of pesticide exposure. Ultimately, everything rests on the individual being cautious and careful when in close contact with a pesticide. Adults should take responsibility for protecting children from pesticide exposure.

The high morbidity and mortality from organophosphate toxicity in developing countries are well known. Therefore, in order to emphasize the health risks from organophosphate insecticides, this article has focused on organophosphates in the United States, where there is less exposure. Given that organophosphate exposure is highly prevalent and is still a major public health issue in the United States, this article clearly shows that there is an even greater need for public health protection from pesticide toxicity in developing countries. Unfortunately, economic limitations in the developing world will delay the development and implementation of effective preventive measures for pesticide toxicity.

\section{REFERENCES}

1. Ecobichon DJ. Toxic effects of pesticides. In: Klaassen CD, Doull J, eds. Casarett and Doull's toxicology: the basic science of poisons. 5th ed. New York; 1996. Pp. 643-689.

2. Sullivan JB Jr., Blose J. Organophosphate and carbamate insecticides. In: Sullivan JB, Krieger GR, eds. Hazardous materials toxicology: clinical principles of environmental health. Baltimore, Maryland, United States of America: Williams and Wilkins; 1992. Pp. 1015-1026

3. Schenker MB, Albertson TE, Saiki CL. Pesticides. In: Rom WN, ed. Environmental and occupational medicine. Boston, Toronto, London: Little, Brown and Company; 1992. Pp. 887-920.

4. Brown AE. Restricted use of pesticides [Internet site]. University of Maryland, Maryland Cooperative Extension. Available from: http:// www.pesticide.umd.edu/leaflets/pil2.pdf Accessed 9 August 2002.
5. He F. Neurotoxic effects of insecticidescurrent and future research review. Neurotoxicology 2000;21:839-845.

6. Henao S, Arbelaez MP. Epidemiological situation of acute pesticide poisoning in Central America, 1992-2000. Epidemiol Bull 2002; 23(3);5-9. Available from: http://www.paho. org/English/SHA/be_v23n3-plaguicidas. htm [Internet site]. Accessed 24 February 2003.

7. Das R, Steege A, Baron S, Beckman J, Harrison R. Pesticide-related illness among migrant farm workers in the United States. Int J Occup Environ Health 2001;7:303-312.

8. Kwong TC. Organophosphate pesticides: biochemistry and clinical toxicology. Ther Drug Monit 2002;24:144-149.

9. Riegel B. Organophosphate pesticides [Internet site]. Available from: http://www.krpc. com/proffed/op\%5Cop.cfm. Accessed 6 September 2002
10. Sanborn MD, Cole D, Abelsohn A, Weir E. Identifying and managing adverse environmental health effects: 4. Pesticides. CMAJ 2002;166:1431-1436.

11. Waddell BL, Zahm SH, Baris D, Weisenburger DD, Holmes F, Burmeister LF, et al. Agricultural use of organophosphate pesticides and the risk of non-Hodgkin's lymphoma among male farmers (United States). Cancer Causes Control 2001;12:509-517.

12. Ray DE, Richards PG. The potential for toxic effects of chronic low-dose exposure to organophosphates. Toxicol Lett 2001;120:343-351.

13. Rosenstock L, Keifer M, Daniell WE, McConnell R, Claypoole K. Chronic central nervous system effects of acute organophosphate pesticide intoxication. The Pesticide Health Effects Study Group. Lancet 1991;338:223227.

14. Fenske RA, Lu C, Barr D, Needham L. Children's exposure to chlorpyrifos and parathion 
in an agricultural community in central Washington State. Environ Health Perspect 2002;110:549-553.

15. Litovitz TL, Klein-Schwartz W, White S, Cobaugh DJ, Youniss J, Omslaer JC, et al. 2000 annual report of the American Association of Poison Control Centers Toxic Exposure Surveillance System. Am J Emerg Med 2001; 19:337-395.

16. Muldoon SR, Hodgson MJ. Risk factors for nonoccupational organophosphate pesticide poisoning. J Occup Med 1992;34:38-41.

17. Langley R, Sumner D. Pesticide mortality in the United States 1979-1998. Vet Hum Toxicol 2002;44:101-105.

18. Goozner B, Lutwick LI, Bourke E. Chemical terrorism: a primer for 2002. J Assoc Acad Minor Phys 2002;13:14-18.

19. Engel LS, Seixas NS, Keifer MC, Longstreth WT Jr., Checkoway H. Validity study of selfreported pesticide exposure among orchardists. J Expo Anal Environ Epidemiol 2001;11: 359-368.

20. Mills PK, Zahn SH. Organophosphate pesticide residues in urine of farmworkers and their children in Fresno County, California. Am J Ind Med 2001;40:571-577.

21. Ciesielski S, Loomis DP, Mims SR, Auer A. Pesticide exposures, cholinesterase depression, and symptoms among North Carolina migrant farmworkers. Am J Public Health 1994;84:446-451.

22. Gadon M. Pesticide poisonings in the lawn care and tree service industries. A review of cases in the New York State Pesticide Poisoning Registry. J Occup Environ Med 1996;38: 794-799.

23. Perry MJ, Marbella A, Layde PM. Association of pesticide safety knowledge with beliefs and intentions among farm pesticide applicators. J Occup Environ Med 2000;42:187-193.

24. Elmore RC, Arcury TA. Pesticide exposure beliefs among Latino farmworkers in North Carolina's Christmas tree industry. Am J Ind Med 2001;40:153-160.

25. Lessenger JE. The pesticide-exposed worker: an approach to the office evaluation. J Am Board Fam Pract 1993;6:33-41.

26. Burns CJ, Cartmill JB, Powers BS, Lee MK. Update of the morbidity experience of employees potentially exposed to chlorpyrifos. Occup Environ Med 1998;55:65-70.

27. Fox A, Castillon K. Employee exposure to mevinphos-an organophosphate pesticide. Appl Occup Environ Hyg 2001;16:506-508.

28. Maddy KT, Edmiston S. Selected incidents of illnesses and injuries related to exposure to pesticides reported by physicians in California in 1986. Vet Hum Toxicol 1988;30:246254.

29. Steenland K, Dick RB, Howell RJ, Chrislip DW, Hines CJ, Reid TM, et al. Neurologic function among termiticide applicators exposed to chlorpyrifos. Environ Health Perspect 2000;108:293-300.

30. Acute pesticide poisoning associated with use of a sulfotepp fumigant in a greenhouseTexas, 1995. MMWR 1996;45(36):780-782.

31. Hodgson MJ, Block GD, Parkinson DK. Organophosphate poisoning in office workers. J Occup Med 1986;28:434-437.
32. Geller RJ, Singleton KL, Tarantino ML, Drenzek CL, Toomey KE. Nosocomial poisoning associated with emergency department treatment of organophosphate toxicity-Georgia 2000. J Toxicol Clin Toxicol 2001;39:109-111.

33. Sidhu KS, Collisi MB. A case of an accidental exposure to a veterinary insecticide product formulation. Vet Hum Toxicol 1989;31:63-64.

34. From the Centers for Disease Control and Prevention. Illnesses associated with occupational use of flea-control products-California, Texas, and Washington, 1989-1997. JAMA 1999;282:125-126.

35. Nolte KB, Taylor DG, Richmond JY. Biosafety considerations for autopsy. Am J Forensic Med Pathol 2002;23:107-122.

36. McCauley LA, Rischitelli G, Lambert WE, Lasarev M, Sticker DL, Spencer PS. Symptoms of Gulf War veterans possibly exposed to organophosphate chemical warfare agents at Khamisiyah, Iraq. Int J Occup Environ Health 2001;7:79-89.

37. Landrigan PJ. Illness in Gulf War veterans. Causes and consequences. JAMA 1997;277(3): 259-261.

38. United States of America, Department of Health and Human Services, Department of Defense, Department of Veteran Affairs. Chemical warfare agents [Internet site]. Available from: http://www.gulflink.osd.mil/ medsearch/FocusAreas/chemical_warfare. shtml. Accessed 9 August 2002.

39. Whyatt RM, Camann DE, Kinney PL, Reyes A, Ramirez J, Dietrich J, et al. Residential pesticide use during pregnancy among a cohort of urban minority women. Environ Health Perspect 2002;110:507-514.

40. Lu C, Knutson DE, Fisker-Anderson J, Fenske RA. Biological monitoring survey of organophosphorus pesticide exposure among preschool children in the Seattle metropolitan area. Environ Health Perspect 2001;109:299-303.

41. Lemus R, Abdelghani A. Chlorpyrifos: an unwelcome pesticide in our homes. Rev Environ Health 2000;15:421-433.

42. Melum MF. Emergency organophosphate toxicity. Am J Nurs 2001;101:57-58.

43. Kass R, Kochar G, Lippman M. Adult respiratory distress syndrome from organophosphate poisoning. Am J Emerg Med 1991;9:32-33.

44. Lewis RG, Fortune CR, Blanchard FT, Camann DE. Movement and deposition of two organophosphorus pesticides within a residence after interior and exterior applications. J Air Waste Manag Assoc 2001;51:339-351.

45. Fenske RA, Kedan G, Lu C, Fisker-Andersen JA, Curl CL. Assessment of organophosphorous pesticide exposure in the diets of preschool children in Washington State. J Expo Anal Environ Epidemiol 2002;12:21-28.

46. MacIntosh DL, Kabiru CW, Ryan PB. Longitudinal investigation of dietary exposure to selected pesticides. Environ Health Perspect 2001;109:145-150.

47. Suhre FB. Variability in pesticide residuesthe US experience. Food Addit Contam 2000; 17:497-501.

48. Renner R. Farm kids and chlorpyrifos. An accurate assessment of exposure. Environ Health Perspect 2002;110:A257.
49. Kahn E, Berlin M, Deane M, Jackson RJ, Stratton JW. Assessment of acute health effects from the Medfly Eradication Project in Santa Clara, California. Arch Environ Health 1992; 47:279-284

50. From the Centers for Disease Control and Prevention. Surveillance for acute pesticiderelated illness during the Medfly Eradication Program-Florida, 1998. JAMA 1999;282: 2204-2206.

51. Miller JR. The control of mosquito-borne diseases in New York City. J Urban Health 2001; 78:359-366.

52. Thier A. Balancing the risks: vector control and pesticide use in response to emerging illness. J Urban Health 2001;78:372-381.

53. Crinnion WJ. Environmental medicine, part 4 : pesticides-biologically persistent and ubiquitous toxins. Altern Med Rev 2000;5:432-447.

54. Dribben WH, Kirk MA. Organ procurement and successful transplantation after malathion poisoning. J Toxicol Clin Toxicol 2001; 39:633-636.

55. Zivot U, Castorena JL, Garriott JC. A case of fatal ingestion of malathion. Am J Forensic Med Pathol 1993;14:51-53.

56. Blazes Dl, Lawler JV, Lazarus AA. When biotoxins are tools of terror. Early recognition of intentional poisoning can attenuate effects. Postgrad Med 2002;112:89-92.

57. Su M, Hoffman RS. Biological and chemical hazards. Nerve agents: pathophysiology, assessment, and management. Resid Staff Physician 2002;48:25-33.

58. Ohbu S, Yamashina A, Takasu N, Yamaguchi T, Murai T, Nakano K, et al. Sarin poisoning on Tokyo subway. South Med J 1997;90:587-593.

59. Bjornsdottir US, Smith D. South African religious leader with hyperventilation, hypophosphatemia, and respiratory arrest. Lancet 1999;354:2130.

60. Higgins GM, Muniz JF, McCauley LA. Monitoring acetylcholinesterase levels in migrant agricultural workers and their children using a portable test kit. J Agric Saf Health 2001;7: 35-49.

61. McConnell R, Cedillo L, Keifer M, Palomo MR. Monitoring organophosphate insecticideexposed workers for cholinesterase depression. New technology for office or field use. J Occup Med 1992;34:34-37.

62. Ames RG, Brown SK, Mengle DC, Kahn E, Stratton JW, Jackson RJ. Protecting agricultural applicators from over-exposure to cholinesterase-inhibiting pesticides: perspectives from the California programme. J Soc Occup Med 1989;39:85-92.

63. Food and Agriculture Organization of the United Nations, World Health Organization. Joint $\mathrm{FAO} / \mathrm{WHO}$ meeting on pesticide residues (JMPR) [Internet Site]. Available from: http://www.who.int/pcs/jmpr/jmpr. htm. Accessed 26 February 2003.

64. Kimmel CA, Makris SL. Recent developments in regulatory requirements for developmental toxicology. Toxicol Lett 2001;120:73-82.

65. Arcury TA, Quandt SA, Russell GB. Pesticide safety among farmworkers: perceived risk and perceived control as factors reflecting environmental justice. Environ Health Perspect 2002;110 Suppl 2:233-240. 
66. Astroff AB, Young AD. The relationship between maternal and fetal effects following maternal organophosphate exposure during gestation in the rat. Toxicol Ind Health 1998; 14:869-889.

67. Sherman JD. Chlorpyrifos (Dursban)-associated birth defects: report of four cases. Arch Environ Health 1996;51:5-8.
68. Banerjee J, Ghosh P, Mitra S, Ghosh N, Bhattacharya $\mathrm{S}$. Inhibition of human fetal brain acetylcholinesterase: marker effect of neurotoxicity. J Toxicol Environ Health 1991;33: 283-290.
Manuscript received 27 September 2002. Revised version accepted for publication 4 March 2003.

RESUMEN Objetivo. Repasar la importancia para la salud pública de la exposición a plaguicidas organofosforados en los Estados Unidos de América. En vista de que la situación en torno a dicha exposición y a los riesgos de salud que la acompañan en países en desarrollo son asunto muy conocido en el mundo, este artículo busca resaltar la importancia de la exposición a esos productos en los Estados Unidos, donde es menos común que en muchos otros países. Esta ojeada a la situación en Estados Unidos sirve para resaltar aun más la gravedad de los problemas de salud que plantea la exposición a los plaguicidas organofosforados en los países en desarrollo.

Métodos. Se llevó a cabo una búsqueda de artículos de revistas sobre los plaguicidas organofosforados y la exposición a ellos que figurasen en PubMed, sistema bibliográfico electrónico de la Biblioteca Nacional de Medicina de los Estados Unidos. Con el fin de suplementar esa búsqueda, se obtuvo de artículos, libros y sitios en la Web información acerca de la toxicidad de los productos organofosforados, su control biológico y su regulación.

Resultados. Los plaguicidas organofosforados son un grupo de productos químicos que se usan principalmente en la agricultura. Dichos productos inhiben la actividad de ambas colinesterasas - la eritrocítica y la sérica-, lo cual explica las manifestaciones colinérgicas que acompañan a la intoxicación por los organofosforados. Una reducción de $50 \%$ de la actividad de la colinesterasa sérica con respecto a su valor basal indica que hay toxicidad aguda por efecto del producto organofosforado. La actividad de la colinesterasa eritrocitaria, que se deprime con menos rapidez que la actividad de la colinesterasa sérica, es indicadora de exposición crónica a productos organofosforados. La exposición a estas sustancias se clasifica en dos categorías generales: la ocupacional y la ambiental. Las exposiciones ocupacionales se producen en agricultores (entre ellos los trabajadores itinerantes), obreros industriales, exterminadores de plagas y otros trabajadores. La exposición que no es de tipo ocupacional afecta a un amplio sector de la población general en Estados Unidos. Las exposiciones residenciales obedecen al uso de plaguicidas organofosforados por exterminadores de plagas y habitantes del hogar, o son de carácter alimentario o accidental. Otras exposiciones ambientales se observan en lugares públicos y en la vecindad de granjas, o bien como resultado del uso de productos organofosforados en casos de guerra química o de terrorismo. En Estados Unidos el uso de algunos plaguicidas organofosforados se ve restringido por la Agencia de Protección Ambiental, habida cuenta de la necesidad de proteger a los seres humanos, los animales y el medio ambiente. Por otra parte, la Ley para la Protección de la Calidad de los Alimentos regula la exposición alimentaria a los plaguicidas, especialmente en el caso de niños menores de un año y de mayor edad.

Conclusiones. Los plaguicidas organofosforados siguen planteando un peligro para la salud de las personas en Estados Unidos. Es necesario realizar una vigilancia biológica de estas sustancias a fin de controlar las exposiciones ocupacionales a ellas y de proteger la salud y seguridad de los trabajadores. Al público se le debe inculcar mayor conciencia del peligro que representa este tipo de exposición ambiental y de la posibilidad de una guerra o ataque terrorista. 